\title{
Breaking Down the 'One-Size- Fits-All' Approach to Rural and Regional Policy: Enhancing Policy Initiatives through Multi-level Governance
}

\author{
Katherine A. Daniell, Anthony Hogan and Jen Cleary
}

\section{Introduction}

Key Australian rural and regional policy challenges: A brief overview

With the prospect of continuing climate change and the emergence of the Asian century, Australia faces a range of likely impacts on, and policy challenges associated with, food production and natural resource management. Such impacts and changes have included the further intensification of agricultural processes owned by international interests, as well as the intensification of ore, coal and gas extraction, coupled with large-scale policy-reform programs targeted at water management, resources, infrastructure development and structural changes to telecommunications. As a consequence, shifting economic outlooks sit at the heart of an agenda for policy change that significantly impacts on rural and regional Australians' livelihoods and wellbeing. 
Yet, change is not unusual in rural and regional Australia (Hogan and Young 2015). The agricultural base that has underpinned the viability of many rural communities has been declining over many years as a result of a sustained technological revolution, which has led to an annual productivity improvement rate of 2.7 per cent since the $1960 \mathrm{~s}$ (Productivity Commission 2005). Such productivity gains are argued to 'be of benefit to some farmers only if others were subsequently forced from their farms' (Barr 2009: 11). Barr (2009), writing on the transformation of Australian farming communities, argues further that, as the number of farmers decreases, the remaining number of farms must increase in size and continue to achieve technological efficiencies, including reducing the need for rural labour.

He points out that the loss of agricultural jobs has a flow-on effect in rural towns, with young people seeking employment in other industries and other towns and cities. The Bureau of Rural Sciences (2008) reported that, for the 10 years ending 2006, jobs in agriculture had fallen proportionately by one-third, moving from 4.4 per cent of total employment in Australia in 1996 to 3.1 per cent in 2006. In particular, a booming Australian mining industry has been increasingly competing for labour in rural and regional agricultural production areas, which, while welcomed in some regions, causes serious challenges for others. The educational needs of children, teenagers and young adults wanting to pursue studies or broader cultural experiences that are not available in their communities is also a driver of outwards migration and a key concern for the future of some rural communities (e.g. Pearson and Dare 2014).

Independent of the process of rural decline and/or structural change, but also exacerbating it, has been the process of climate change and the impacts of dryness. Increasingly, many small-scale farmers find that they cannot compete within the structure of existing globalising markets and an increasingly unstable climate (Hogan et al. 2010), while, at the same time, large-scale multinational interests are investing in farming at a geographic scale not seen before. These businesses have access to such levels of capital as to be able to climate-proof themselves against changes of weather and climatic trends by owning productive resources in a variety of countries and regions within countries, such that they can farm one region but not another, depending on where, when and how often rain falls or water allocations for irrigation are available. Environmental degradation - including loss of biodiversity and soil health through land salinisation, acidification and the loss of topsoil, as well as serious damage 
to water-dependent ecosystems such as rivers and wetlands through overuse and invasive species - is also a major challenge, as it typically underpins agricultural productivity (in the case of soil) or other industries vital to rural and regional communities, such as tourism.

\section{The state and drivers of Australia's rural and regional governance system}

The governance of rural and regional Australia seems as confused as it is complicated. Evans et al. (2013) highlight that, rather than streamlining the complexities of governance in this space, successive Australian governments have introduced new agencies and decision-making processes that are set up to work around entrenched decision-making processes at lower levels. The intensified layering of administrative and institutional arrangements, not to mention the duplication of decisionmaking processes in rural and regional Australia, is further complicated by a lack of clear vision for policy in this space (Hogan and Young 2013). Community-based governance processes are also almost systematically altered when there is a change in the Australian Government, as was the case for the Julia Gillard's Labor Government (2010-13), which reinvigorated notions of localised decision-making. This was, albeit, a form of (centralised) managerial localism (Evans et al. 2013) where local bodies were given some say in the development of some local initiatives, subject to the wishes of the Commonwealth Minister for Regional Development.

The importance of crises, such as intense floods, droughts or global economic events, can also not be overlooked as drivers for the development of these complex governance arrangements as such events help to mobilise action around governance changes and provide a window of opportunity for legislative reform in conflict-ridden policy spaces (e.g. Sabatier 1988; Dovers 2013; Daniell et al. 2014). The 'Millennium drought' in Australia, which officially ended in 2012 (Age 2012), was certainly one such event that mobilised policy change in the governments of John Howard and Kevin Rudd - Gillard governments, such as the Water Act 2007 and the associated federal takeover of Murray-Darling Basin (MDB) governance.

With the spending of $\$ 4.5$ billion in exceptional circumstances (EC) assistance payments from 2001-12, there was also increased impetus for drought policy change in the agricultural policy domain. This was especially due to fears that climate step-changes in south-western Australia and south-eastern Australian might be permanent and linked 
to climate change (e.g. Wentworth Group 2006), which would make the financial undertakings of the current policy system untenable into the future. In response, an intensification of drought policy work was evident, underscored by values that construct the global challenges of farming as risks that are inherently internal to businesses and, as such, a risk to be carried by the individual entity.

In particular, the Gillard Government went to extensive lengths to encourage the nation's farmers to adapt to the challenges of climate change, while the Intergovernmental Panel on Climate Change continued to document the extent, impact and likely future scenarios of global warming and the acidification of oceans on Australia's weather patterns and capacity to pursue agriculture in given parts of Australia. A distinct climate-impact line was identified in the West Australian wheat belt, where a casual observer can stand and observe the point in the wheat paddocks (east of Merredin) where the rain has stopped falling and where it is unlikely wheat will grow again. A new drought policy trial was implemented in this region (DAFF 2010; ABARES 2012) with the possibilities of rolling measures of it out nationally if it was seen to be successful through part of the Intergovernmental Agreement on National Drought Program Reform, ${ }^{1}$ signed under the Gillard Government in 2013.

With the subsequent election of the Liberal conservative government under Tony Abbott in late 2013, policy directions changed, with the government bringing to a halt or deprioritising many of the former government's efforts to address either the impacts of climate change or the environmental impacts of increasingly intensified farming. In the 2014 budget, the Abbott Government withdrew approximately $\$ 500$ million in funding for the care of land in Australia, despite the serious challenges of soil salinity, acidification, erosion, loss of top soil, and pollution and overuse of many of the nation's waterways. It also sought to wind-up the National Water Commission by the end of 2014. By contrast, a further $\$ 1$ billion has been allocated to the development of critical infrastructure to support the more efficient export of primary resources overseas by road and through seaports.

1 www.agriculture.gov.au/SiteCollectionDocuments/agriculture-food/drought/drought-programreform/iga.pdf. 
Amidst these typical swings in national policy, people living in rural and regional areas have to suffer through the lack of coherence and consistency in policy strategies that have important impacts on their day-to-day lives. There are multiple levels of government and a multiplicity of interests at work in the governance of rural and regional Australia, and it appears to be a far from effective form of governance. Yet, many people continue to express the desire to live in rural and regional Australia and to develop their livelihoods there (Gross and Dumaresq 2014). Others just want to see it prosper as it is an important part of the Australian nation, which is said to be have been built 'on the sheep's back' and agricultural development more broadly, and/or have its environmental qualities preserved for the future generations. Here, Australians concerned about the environment look for coherence in environmental policy (Tennent and Lockie 2015), while people who rely on the rural space tend to look at the nation's economic settings and question how such policy design could possibly be in the interests of small-scale family farmers and similarly sized rural communities (Smith and Pritchard 2015).

\section{Proposal for a way forward}

In this complex policy context of often competing values, rural and regional Australia desperately needs a well-developed and considered form of 'multi-level governance' (MLG) - a system of governance where mechanisms exist that provide for arenas of 'continuous negotiation among nested governments at several territorial tiers' (Marks 1993), where authority is not only dispersed vertically between levels of administration, but also horizontally across different sectors of interest and spheres of influence, including non-government actors, markets and civil society (see Daniell and Kay). Over the past few years, scholars have described how such systems of governance could be developed (see, for example, Botterill 2011; Cockfield 2015; Collits 2015; Hogan et al. 2015). The Commonwealth's approach to the development of institutional structures and policy implementation processes, however, appears to continue to diverge significantly, in that they are typically 'one-size-fits-all' approaches where power is devolved to the federal or state government, depending on the issue.

In taking government in September 2010, Julia Gillard announced a new era in governance (discussed below). Yet, since the Abbott-led Coalition's election victory in 2014, governmental departments continue to operate 
within basically the same processes and structures as usual. Thus, central to progressing governance in rural and regional Australia, is the need to embrace principles and processes of MLG to enhance these current and longer-term policy initiatives. But how could this come about and why might such moves be justified?

First of all, we suggest that MLG can be used as a potential way of moving beyond current forms of policy centred on values of centralised commandand-control (including managerial localism), to open up possibilities of a more flexible and dynamic approach to decision-making - one that requires continuous negotiation, interaction and revised funding models. We consider that the central tenet of 'negotiated policies' as outputs of MLG processes implies that one-size-fits-all policies are unlikely to result because individual communities and other stakeholders will likely have the opportunity to negotiate appropriate place- and need-specific mechanisms or policies with higher levels of governments, businesses and non-government organisations, which will vary from community to community.

By 'appropriate' mechanisms, a range of MLG arrangements could be imagined where policies are developed. For example, in some cases, it could be envisaged that multi-level negotiation systems are developed between federal and local governments, communities and businesses, effectively bypassing the states, if decision-making processes do not require them (Daniell et al. 2014). Efforts to develop such an approach for specific water policy initiatives have already been observed with the federal government negotiating with, and directly funding, local communities for local policy initiatives (e.g. Kelly 2010). Other systems - for example, for natural resource management that is strongly spatially constrained - may require more nested 'polycentric' (Ostrom 1999; Marshall 2008) or 'adaptive' (Pahl-Wostl 2008) governance structures. The challenge here remains to ensure that no important spatial or administrative/institutional levels are neglected and that effective cross-scale linkages and negotiation systems are developed to support them (Berkes 2002; Cash et al. 2006; Daniell and Barreteau 2014).

In the next sections, we expand our argument by reviewing some current issues and approaches in policymaking arising in the context of global changes and the regional policy agenda, and consider them in the context of the principles of MLG. The analysis relies not only on literature and policy reviews, but also on research and interviews carried out as part of the 
Cotton Catchment Communities Co-operative Research Centre (CRC); a Rural Industries Research and Development Corporation-funded project, 'Securing the Wealth and Wellbeing of Rural Communities', undertaken between 2012 and 2014 (Hogan et al.2014); and the 'Building Adaptive and Sustainable Communities in the Murray-Darling Basin' project of the MDB Futures Collaborative Research Network (2012-14). Bringing these materials together, we then propose a way forward for the development of governmental conditions that could allow for more power-sharing, flexible financing and cross-sectoral capacity development in the field of Australian rural and regional policy.

\section{Issues and approaches arising in Australian regional policy practice}

Within regional Australia, there is significant diversity in income levels (Lloyd et al. 2001), employment rates (Garnaut et al. 2001) and mixes of both high and low productivity. Regions may have differing histories of settlement patterns and migration (Hugo 2001) and differences in both the pace and nature of development. Some regions have highly diverse local economies, or larger, more demographically diverse populations concentrated in relatively small areas (e.g. regional Victoria), while other regions are dominated by a single industry or a few industries that are agglomerative in nature and contain smaller and less demographically diverse populations spread over vastly greater spatiality (e.g. remote South Australia, Northern Territory and Western Australia).

Smaller and/or remote communities in geographically large regions, in particular, are highly interconnected across sectors, operate systemically and rely heavily on economies of scope rather than scale (Cleary 2014). In these regions, where distance and low-density populations are a feature, resources are often shared across different sectors so as to minimise higher overhead costs associated with productivity and service provision (Carson and Cleary 2010). They also, however, tend to rely on the same people to lead initiatives and community development or maintenance activities, with many community members struggling to manage the load of work required (Drought Policy Review Expert Social Panel 2008; Collaborative Research Netword (CRN) Project interviews 2013-14). 


\section{The Regional Development Australia initiative}

In the period since 1996, successive Australian governments (regardless of political affiliation) have increasingly withdrawn from regional development, arguing that this falls constitutionally within the bailiwick of state and territory governments (Maude 2004). Following the installation of the Rudd and Gillard governments in 2007 and 2010, however, Australia moved towards new institutional arrangements that purported to link federal, state and local governments in supporting regional development through the Regional Development Australia (RDA) initiative (Albanese 2008). Federal involvement in regional Australia policy further intensified through the Gillard Government and its signing of an agreement with a group of independent members of federal parliament that provided a basis for specifically addressing the needs of rural and regional Australia. The agreement provided for the establishment of a Department of Regional Australia, and funds for infrastructure development for rural and regional Australia. In announcing this agreement, Gillard, echoing her predecessor's views (APSC 2009), said that Australia was entering a new era of governance, where one-size-fits-all policies would no longer work. We can immediately see here the presence of contrasting perspectives on the governance of regional Australia, with positions shifting considerably from one with more clearly demarcated lines of responsibility and limited accountability to one with far more enmeshed forms of interaction that lack an articulation of either policy strategy or lines of accountability through local and state governments (see also Mulgan for discussion of accountability in MLG systems).

Despite its apparent intentions in putting its new RDA structure in place, however, the Gillard Government ended up pursuing a one-size-fits-all policy. In Victoria, Queensland, Western Australia and the Northern Territory, the RDA structure directly replaced existing area consultative committees and sat alongside existing regional development structures. In South Australia, Tasmania and New South Wales, the structure was superimposed over existing arrangements; that is, both area consultative committees and regional economic development boards were replaced by RDA committees. In South Australia and New South Wales, for example, regional economic development was vigorously pursued by regional economic development boards through a range of projects, programs and service delivery, while area consultative committees acted in an advisory role to the Australian government but without direct involvement in 'onground' projects or service delivery. 
This RDA policy implementation process did not take into account preexisting governmental arrangements or differences in regional decisionmaking. It also ignored the existing internal process that the various local bodies had developed to meet the diversity of contextual challenges that exist among regions. It also ignored the different foci that have historically determined the activities undertaken by the various regional bodies and it ignored existing reporting processes, imposing a new set of reporting requirements that were mirrored across all states and territories, despite the differing operational arrangements that existed prior to the creation of the new structure. In the case of the RDA initiative, economies of scale related to funding requirements and reporting employed to achieve efficiencies within government departments increased the burden on these RDA bodies and thus created inefficiencies at the local scale.

The development and implementation of this RDA policy certainly did not appear to stem from negotiations between existing community, regional and government bodies, as a more connected MLG system approach would suggest but, rather, were imposed from above with little consultation. ${ }^{2}$ In the face of climate change and other global changes, however, the fundamental imperative will be for regional, rural and remote communities to adapt to the changing environmental conditions that will affect their sustainability and capacity for development. At the local and regional level, this will undoubtedly require the flexibility to respond appropriately to the contextual factors that continue to shape these communities.

A flexible policy and regulatory environment in which suitably tailored adaptation approaches can be enacted is, therefore, critical. Such arrangements need to support appropriate institutional social infrastructure that is responsive to regional difference and, most importantly, nimble and flexible enough to enable local responses to local conditions. This analysis would imply a potential need to change the current RDA policy to increase its flexibility and break down the one-size-fits-all implementation process.

Under the Abbott Government, RDAs were retained, albeit with a stronger focus on local economic development rather than the broader realm of social inclusion that was the case under the previous government.

2 CRN interview respondents also note that, in implementation, the RDAs are structured in a way that supports a stronger government directive approach, rather than the more collaborative nature of previous regional area consultative committees, but that individual RDAs are attempting to make the best of the new arrangements for their communities. 
Deputy prime minister Warren Truss, in his address to the 2014 SEGRA (Sustainable Economic Growth for Regional Australia) conference delegates in Alice Springs (Truss 2014) announced changes to RDA governance whereby chairs and deputy chairs would be appointed by the Australian Government, and committee members would be appointed by chairs. He also highlighted the current situation in which some states have tripartite arrangements, as outlined above, and said that this would continue to be supported in those states and territories. His address signalled that, while the federal government 'still had an important role to play in supporting economic development in all regions' and would continue to work closely with all RDA committees, it would take a more 'hands off approach and seek to streamline administrative and reporting requirements:

I have taken time to consider the structure based on the views of all stakeholders. I have spoken with state and territory ministers responsible for regional development, my parliamentary colleagues, many RDA committee members, as well as representatives of the community in the hope that it might be possible to develop a model where all three tiers of government worked together to sponsor a well resourced national network of regional development organisations working to grow stronger regions across the nation ... but the prospects of all states agreeing to participate in a common RDA network anytime soon seems remote. I hope the goal will be achieved one day (Truss 2014).

In other words, Truss considered that developing formal coordination (or 'meta-governance') of multi-level RDA governance systems across the country was at the time too challenging. This could leave room for more freedom to 'fit' RDA work to local needs, but only a fuller evaluation of the system would allow this to be investigated.

One other linked area of policy flexibility that requires particular attention is the current existence of funding silos between RDAs and rural industry-focused research and development corporations (RDCs). Price (2015: 226) points out that Australia invests a significant amount (approximately $\$ 3$ billion per annum) in research and development associated with such industries. We note, however, that there often appears to be little interface between research that is focused on rural industries and the communities in which those industries operate. The question needs to be asked as to how the notion of 'regional development' can be effectively enacted when the research and development process operates largely independent of regional planning. Ideally, the gap between 
these processes needs to be bridged to enhance future rural and regional development. Embedding research and researchers in regional Australia may be one means of working towards that goal.

In October 2017, the Turnbull Government completed a review of the RDA Committees' structures and functions. The review proposed a new that focus 'on growing strong and confident regional economies ... in order harness innovation and drive economic growth'. Such growth, the charter suggests, would result from 'creating local jobs, attracting investment and driving innovation' (RDA 2017). Comments from the 2016 Regional Development Australia National Forum showed that, despite a number of challenges reflecting those already discussed, RDAs are increasingly seen as creating significant value in the regions as 'honest brokers' between local, state and federal governments, and they are indeed becoming increasingly 'agile, flexible and independent' in their ways of functioning. ${ }^{3}$ Despite a top-down beginning, significant bottom-up and collaborative working arrangements and contextualisation of the RDAs over their lifespan have emerged in many instances, demonstrating the transient nature of MLG systems. Such transitions and common patterns in MLG system changes will be explored in more depth in the conclusion (Daniell and Mercer).

\section{Drought policy adjustments and the guide to the draft Murray-Darling Basin Plan}

The command-and-control approach to federal policy development and implementation is not unique to the RDA process. Other significant regional government policies have been developed, or at least started out, with minimal or one-sided consultative processes. An expert social group convened extensive and independent consultations to establish a drought policy. This group reported its findings to government (Drought Policy Review Expert Social Panel 2008). The government, in turn, developed its policy and proceeded to pilot it, without open consultation, in a specific part of Western Australia. Policy advocates and farmers across the eastern seaboard were concerned by this process, as the findings of the pilot were likely to have widespread ramifications for farming across Australia,

3 Based on comments contained in the notes from participants in the forum: rda.gov.au/nationalforum/files/20161116-Regional-Development-Australia-National-Forum.pdf [Accessed: 12/04/2017]. 
although they also acknowledge the issues concerning the existing EC policy. ${ }^{4}$ The proposed guide to the Murray-Darling Basin Plan (MDBA 2010) was launched in a similar way.

Consultants were hired to prepare specific pieces of scientific work, and a small community advisory committee was consulted to inform the governmental policy development process run by the new, independent Murray-Darling Basin Authority (MDBA). An outcome was then announced to the Australian community, which was followed by a highly mediatised barrage of critique and anger. Independent federal politician Tony Windsor, responding to the intense level of community backlash against the plan, observed that a way forward that addressed the water needs of the river system and the viability of rural communities would need to be worked out on a 'valley by valley or even town by town basis'. The diversity of rural and regional communities across the basin would require a flexible approach that could drill down to the community level, rather than the current one-size-fits-all top-down approach, if even 'better-better' (rather than 'win-win') solutions were to be hoped for (ABC 2010).

Similarly, in the research undertaken in rural communities across Australia within the 'Securing the Wealth and Wellbeing of Rural Communities' project (Hogan et al. 2014), we found that policies and the commandand-control approaches to their implementation across both federal and state jurisdictions were often cited by project participants as impacting on the viable futures of those communities. For example, in Tasmania, the federal policy decision to connect 'spoke' communities to the new National Broadband Network (NBN) before larger 'hub' communities (in an attempt to benefit those rural communities seen to be most in need of broadband services to progress economic growth through digital business opportunities) 'failed dismally' in the words of one interviewee.

Without the required economies of scale achievable in connecting multiple users in larger communities (e.g. Launceston), participants reported that one major telecommunications company was reluctant to change their service provision model in the smaller communities because initial implementation costs were too high. This resulted in subscribers

4 For example, community tensions about appropriate farm management and equity were observed around the policy in CRN interviews, as exemplified by the comment: 'The people who had been tight and saved money when it came to Exceptional Circumstances couldn't access money, yet those who splashed money around and had nothing in reserve received Exceptional Circumstances.' 
to that company in those communities often having to stay with this service provider until broadband services were available through that provider, or maintain mobile telephony service with that provider (due to contractual requirements of post-paid service plans) and subscribe to a different service provider (who was providing NBN connections) for the new broadband internet services. In this instance, project participants cited a lack of engagement and consultation along with knowledge gaps about how on-ground services work as the primary unintended consequences of the policy decision. Indeed, we found that engagement, consultation and a knowledge of the differing social and economic situations of rural communities were fundamental factors in assisting rural communities to plan for their futures (Cleary and Carson 2014).

\section{Potential for moving beyond one-size-fits-all}

Before moving to consider how more flexible mechanisms of policy development may be realised, it is first necessary to step back for a moment and consider current methods of development and implementation of policy strategy. Hogan (2010) reports on several key ways in which policy is developed in Australia. Just some of these include: policy that is politician-driven (e.g. the current agreement for regional Australia); reactive policy, often politician-driven in response to media reports and public outcry (e.g. a parliamentary inquiry to quell anger on the guide to the basin plan); policy that comes up through government department internal policy development processes (e.g. the current draft drought policy and asylum seeker detention centre site choice); and policy driven through the Council of Australian Governments (COAG).

The problem with these processes, as Hogan (2010) observes, is that they do not generally provide mechanisms for systematic and well-organised public participation and broader stakeholder engagement in decisionmaking. Rather, policies are developed within the closed processes of government departments or in the shadows of Parliament House. Such governmental policy development processes often follow the adage of decide, promote, defend (and amend if you have to). Consultations, when they occur (e.g. for drought policy process and the guide to the basin plan), are typically one-sided, allowing the hearing of only limited views from the public and without the identification of further opportunities for the public to participate in discussions. Such processes in contentious 
policy areas are well known to incite widespread backlash and run the risk of developing locally inappropriate and unimplementable policies (Daniell 2012), as well as disempowering communities (Arnstein 1969).

Other internalised governmental policy development processes do provide for a level of consultation and negotiation between the Commonwealth and the jurisdictions, for example in the two-tiered decision-making processes of ministers and departmental heads that feeds into COAG (e.g. the Primary Industries Ministerial Council and its Primary Industries Standing Committee, as well as the Natural Resource Management Ministerial Council and its Natural Resource Management Standing Committee). Typically within such processes, the bureaucracy tables its policy issues and concerns through heads of department. Once a consensus position or series of options is agreed upon, recommendations go to the ministerial committee for endorsement and, where appropriate, a request is made for action or endorsement through COAG.

While the agendas that such committees address can be seen on public websites, the processes do not provide for open public and stakeholder participation in the policy development process. What it does allow for is the opportunity for well-organised and resourced interest groups to lobby policymakers, with a view to influencing decision-making. The workings of such processes are readily open to participant observation in the everpopular coffee shops conveniently situated on the ground floor of most Commonwealth government departments in Canberra. More independent bodies, such as statutory authorities (e.g. Safe Work Australia), sometimes provide for more broadly based public and stakeholder participation in decision-making where representatives of industry and unions have a seat at the decision-making table and an opportunity to negotiate with the authority. But again, the process is far from transparent and open in engaging stakeholders from different jurisdictional levels.

The funding mechanism underpinning federal policy development in Australia can be as critical to the success of federal initiatives as the concepts within the policy itself. Commonly within the federal budget, funds may be allocated to a policy strategy wherein such funds must be expended within the existing financial year. With budgets typically announced in May, it is not uncommon for such projects to be initiated late in the calendar year, with the requirement that projects be completed by 30 June the following year. Such funding strategies provide little opportunity for projects to develop the necessary synergies and momentum to address 
entrenched policy problems. To address substantive policy problems, funds need to be allocated to policy strategies with much longer time frames in place, and be provided for projects that can run over many years.

An increasingly global issue is the expectation from citizens that they have the right to participate in all aspects of decision-making that impact upon them if they feel the desire to do so, as well as that decision-making processes are underpinned by a policy of transparency. Commentators note that it is not only democratic legitimacy issues that are driving open and inclusive approaches to policy development, but also the need to develop implementable policies that have the best chance of being successful while minimising unintended consequences. This is as the knowledge, resources and authority to make and implement decisions are increasingly dispersed between a large range of stakeholders, including different levels of government, management bodies, research organisations, private companies, non-government organisations and the general public (Rhodes 1988; Fischer 2000; Daniell et al. 2010a, 2010b). Mike Oliver's (1990; 1996) work on disability policy, following the adage of nothing about us without us, ${ }^{5}$ serves as an excellent example of this work from the perspective of an international movement.

More locally, however, Australia has witnessed a range of alternative policy development processes that have begun to embrace more open MLG approaches to decision-making. ${ }^{6}$ Such processes were also evident in a social-planning approach developed at the state government level and involving close collaboration by the state government with local government and community organisations. For example, the process known as area assistance schemes ${ }^{7}$ was concerned with the allocation of limited resources that were available to address the priority community infrastructure needs of disadvantaged and developing communities. Local priorities were established through an annual community consultative rating process that was informed by needs analysis (e.g. local community profiles) developed by local government. Community development

5 'Nothing About Us Without Us', Wikipedia contributors, Wikipedia, The Free Encyclopedia, en.wikipedia.org/w/index.php?title=Nothing_About_Us_Without_Us\&oldid=780235527 [Accessed: 29/05/17].

6 'Multi-level Governance Symposium' 12-13 June 2010, Crawford School of Economics and Government, The Australian National University, crawford.anu.edu.au/events/content/ video/?year=2010\&id=31.

7 See, for example, Bamforth et al. (2016). 
officers worked closely with local communities to help them articulate their service needs, to understand the competing needs in the community and to facilitate a community-supported decision-making process.

These concepts of shared levels of systemic disadvantage, competing social needs, the need to be sensitised as to how one is affected, the need for engagement and facilitated social change are common aspects of the social demands placed on rural communities by climate change, amongst other factors. Set before our community is the challenge of how governance processes for rural and regional Australia may be established that facilitate recognition of being affected, of shared social impacts, of the uneven and unavoidable distribution of disadvantage, and the development of socially responsible means of mitigating such effects with a view to securing just and peaceful outcomes across our society. Understanding and developing the potential of appropriate types of MLG processes to open up opportunities for the necessary adaptations to, and mitigations of, the social effects of climate change, therefore, seems a promising way forward to break down the common one-size-fits-all approach to rural and regional Australian policy.

\section{Mapping a way forward for the development of MLG approaches to policy challenges in rural and regional Australia}

As we see it, there is ample evidence of MLG systems having been effectively developed between communities, appropriate levels of government, business and other stakeholder groups that have led to widely acceptable and effectively implemented policies, even if this is often just at a regional rather than national level (see, for, example the following chapters in this volume: Jarvie and Stewart on indigenous policy in the Murdi Paaki region of New South Wales; Mercer and Jarvie on early childhood education reform through COAG; Andrews on the governance arrangements of the Lake Eyre Basin) or international level (see, again in this volume, McNaughton and Lockie on GLOBALG.A.P. standard-setting for agricultural and food products), and improvements could be made (see, for example, in this volume, Dale et al. on Australian natural resource management (NRM) governance systems; Iwanicki et al. on strengthening NRM and urban planning governance system interactions; Hogan on the governance of differences in hearing; and Norman and Gurran on governance arrangements for coastal and climate change planning). 
In fact, following the catastrophic reaction to the release of the guide to the draft of the Murray-Darling Basin Plan, the new CEO of the MDBA sought to change the authority's approach from a top-down one that excluded stakeholders to a 'localism' approach (Knowles 2011; Dare and Daniell 2017) that would engage and value different communities' views and inputs in the negotiations over the construction of the plan. The approach proved successful in that the Murray-Darling Basin Plan was passed by the parliament in 2012 with minimal negative reaction from rural and regional communities.

Our way forward involves distilling the lessons of these effective negotiation systems and adapting their application to policy challenges in rural and regional Australia. This will be an important and ongoing task for researchers, policymakers and stakeholders alike. From the examples briefly outlined in this chapter, we conclude with four priorities that would significantly propel us into the more widespread uptake of MLG approaches to policy challenges in rural and regional Australia.

The first key priority for the endeavour of developing effective MLG systems is the need to develop the enabling conditions at all levels of government that will allow them to move towards power-sharing and continuous negotiation systems that fit the policy challenges of rural and regional Australia. The Australian Public Service Commission has also noted the significance of this challenge (APSC 2009). Therefore, if the federal government is serious about effecting positive change in rural and regional Australia, strong political and bureaucratic leadership is required to reform the way government develops and implements policy, which will enable improved governance systems that function along the principles espoused by the United Nations of being 'participatory, consensus oriented, accountable, transparent, responsive, effective and efficient, equitable and inclusive, and follows the rule of law' (e.g. UNESCAP 2010).

The development of trust between stakeholders, including in governments, is also important, as highlighted by Dugdale, and Jarvie and Stewart. Considering these principles for good governance, an important first step in governance reform is to understand that 'town hall meetings' do not meet half the governance criteria that they are perhaps expected to, namely being participatory, consensus-orientated, effective, efficient, equitable and inclusive (Daniell 2011). This means understanding the mechanisms for engagement of the public that allow active involvement and exchange and the implementation of a range of participatory methods 
to foster dialogue and negotiation to match the needs of the policy issue (see Rosenhead and Mingers 2001; Slocum 2003; and Creighton 2005 for some examples). This expertise in participatory engagement methods already exists in Australia and effort is only required to muster and support its use for the development and delivery of more collectively negotiated, widely accepted and effective rural and regional Australian policy.

The second priority is to attempt to develop improved articulation between centralised rural and regional policy and planning processes and those occurring at more local levels, so that different regions can play a stronger role in envisaging and working towards their preferred futures in a coordinated manner. The European Union (EU) has, for example, introduced the 'Smart Specialisation' platform, supported by a number of coherence policies and structural funds, that is aimed to support regions to develop strategies for growth and to reduce inter-regional inequities. Specifically, the smart specialisation initiative includes:

a focus on identifying niche areas of competitive strength, solving major societal challenges - bringing in a demand-driven dimension, innovation partnerships emphasizing greater co-ordination between different societal stakeholders and aligning resources and strategies between private and public actors of different governance levels. ${ }^{8}$

In the Australian situation, such a focus might involve determining what niche areas of strength different communities have and how these could be better enhanced in the future - for example, through targeted funded linkages with regional university groups and businesses/government services on specific topics (e.g. health care, tourism, cotton, grape production, irrigation efficiency, cultural pursuits) - to build further capacity and economic and community growth in these areas.

Third, broader consideration needs to be given to creating an interface between decision-making in RDCs with RDAs. Collaboration within and across industries, as well as the communities in which rural industries operate, has long been a priority of the Rural Industries Research and Development Corporation. ${ }^{9}$ The reality is, however, that the research plans of RDCs give little regard to collaborations with rural communities, with the possible exception of employment-related research. It seems

8 'Smart Specialisation', EU Science Hub, ec.europa.eu/jrc/en/research-topic/smart-specialisation [Accessed: 29/05/17].

9 See www.rirdc.gov.au/ for more information. 
fundamental, therefore, that an interface needs to be developed between RDCs and RDAs so that more industry research considers the communities within which it operates and that provides community members with the opportunity for real input into the development of publicly funded research and development within their communities. The same could be said for other government-based and academic research on Australian rural and regional policy challenges, including water, environmental, Indigenous and health policy.

Finally, there is the need to draw attention to the important task of 'metagovernance' that focuses on setting up the conditions and rules that can foster MLG systems with 'good governance' characteristics (described in the first priority, above) to develop and thrive. As Jessop (2004) suggests, this meta-governance role, which could be taken on by people inside and outside government, should foster a requisite variety in the types of MLG systems set up, be reflexive and forward thinking, and supervise the combination and implementation of this variety of appropriate systems that meet the needs of the policy issues for which they are developed. Effectively performing this meta-governance role could, therefore, lead to the welcome end of one-size-fits-all policies for remote, rural and regional Australia and give our diverse communities the opportunity to participate actively in developing the policies that are so important for their futures. This is not likely to be a simple task, considering the historical and ongoing tendency to centralise decisions affecting regions and apply them in a standardised manner with little input from communities. For example, in response to a proposal by the NSW Government to appoint regional 'advisory committees', Bland (1944) noted:

and there is no reason to assume that projects for soil erosion, for afforestation, and for electric power will not be handled by the respective central departments now concerned with these things. The effect of this method for promoting regional development is obvious. Whether or not the regions have local representatives on the committees appointed by the Reconstruction Division is immaterial. The committees are purely advisory. Effective control remains at the centre, and the central departments will implement the schemes. In other words, the development of the regional resources will be removed from the control of the people of the regions, and the traditional centralised administration will be more securely established than ever. The effect will be to retard the emergence of any regional consciousness. 
We remain hopeful, however, that a multiplicity of regional and rural 'consciousnesses' will be able to play an integral role in shaping future Australian rural and regional policy reforms, if sufficient energy and resources can be put into the development of more effective and diversified, but still coordinated, MLG systems across the country.

\section{References}

ABARES (2012). Drought in Australia: Context, Policy and Management. Australian Bureau of Agricultural and Resource Economics and Sciences, Australian Government, www.droughtmanagement.info/literature/ GovAustr_drought_in_australia_2012.pdf [Accessed: 26/07/2017].

ABC (2010). Windsor on the Murray Darling. The 7.30 Report, www.abc. net.au/7.30/content/2010/s3038776.htm [Accessed: 28/10/2010].

Age (2012). Minister Declares End of Drought, news.theage.com.au/ breaking-news-national/minister-declares-end-of-drought-201204271xpgi.html [Accessed: 11/12/14].

Albanese, A. (2008). Regional Development Australia. Statement by the Minister for Infrastructure, Transport, Regional Development and Local Government, the Hon Anthony Albanese MP, 20 March 2008.

APSC (2009). Delivering Performance and Accountability. Australian Government, Canberra, www.apsc.gov.au/publicationsand-media/archive/publications-archive/delivering-performance [Accessed: 26/07/2017].

Arnstein, S.R. (1969). A Ladder of Citizen Participation. Journal of the American Institute of Planners, 35(4): 216-24. doi.org/ $10.1080 / 01944366908977225$

Bamforth, J., Gapps, B., Gurr, R., Howard, A., Onyx, J. \& Rawthorne, M. (2016). Planning, Funding, and Community Action The Area Assistance Story. Diversity in Organizations, Communities \& Nations, a book imprint by Common Ground Publishing, Champaign, IL.

Barr, N. (2009). The House on the Hill: The Transformation of Australia's Farming Communities. Land and Water Australia in association with Halstead Press, Canberra. 
Berkes, F. (2002). Cross-Scale Institutional Linkages: perspectives from the bottom up. In: Ostrom, E., Dietz, T., Dolsak, N., Stern, P., Stonich, S. \& Weber, E.U. (eds) The Drama of the Commons. National Academy Press, Washington, D.C.

Bland, F.A. (1944). A Note on Regionalism. The Institute of Public Administration, Australia, pp. 176-82. doi.org/10.1111/j.14678500.1944.tb02045.x

Botterill, L.C. (2011). Fair Share: Correspondence. Quarterly Essay, 43: 129-31.

Bureau of Rural Sciences (2008). Country matters - 2008 Social Atlas of Rural \& Regional Australia - Employment. Department of Agriculture, Fisheries and Forestry, Canberra.

Carson D. \& Cleary J. (2010). Virtual Realities: How remote dwelling populations become more remote over time despite technological improvements. Sustainability, 2(5): 1282-96. doi.org/10.3390/su 2051282

Cash, D.W., Adger, W., Berkes, F., Garden, P., Lebel, L., Olsson, P., Pritchard, L. \& Young, O. (2006). Scale and Cross-Scale Dynamics: Governance and information in a multilevel world. Ecology and Society, 11(2): 8. doi.org/10.5751/ES-01759-110208

Cleary, J. (2014). Recycling Dependency: The Grant Economy Propping up Rural, Regional and Remote Australia. Proceedings of the SEGRA Conference, 7-10 October, Alice Springs.

Cleary, J. \& Carson, D. (2014). Project Engagement. In: Hogan, A., Carson, D., Cleary, J., Donnelly, D., Houghton, K., Phillips, R. \& Tanton, R. (eds) Community Adaptability Tool: Securing the Wealth and Wellbeing of Rural Communities. RIRDC Publication No. 14/041, Canberra, pp. 17-27, rirdc.infoservices.com.au/items/14-041 [Accessed: 12/12/14].

Cockfield, G. (2015). From State Direction to Community Self-Efficacy: the devolution of responsibility for regional development in Australia. In: Hogan, A. \& Young, M. (eds) Rural and Regional Futures. Routledge, London, pp. 38-57. 
Collits, P. (2015). Regional Policy in Post-War Australia: much ado about nothing? In: Hogan, A. \& Young, M. (eds) Rural and Regional Futures. Routledge, London, pp. 19-37.

Creighton, J.L. (2005). The Public Participation Handbook: Making Better Decisions through Citizen Involvement. Jossey-Bass, San Francisco, California.

DAFF (2010). Stronger Rural Communities: Program Guidelines. Australian Government Department of Agriculture, Fisheries and Forestry, Canberra.

Daniell, K.A. (2011). Enhancing Collaborative Management in the Basin. In: Connell, D. \& Grafton, R.Q. (eds) Basin Futures: Water Reform in the Murray-Darling Basin. ANU E Press, Canberra, pp. 413-38.

- (2012). Co-engineering and Participatory Water Management: Organisational Challenges for Water Governance. UNESCO International Hydrology Series. Cambridge University Press. doi.org/ 10.1017/CBO9780511998072

Daniell, K.A. \& Barreteau, O. (2014). Water Governance across Competing Scales: Coupling land and water management. Journal of Hydrology, 519(Part C): 2367-80. doi.org/10.1016/j.jhydrol. 2014.10.055

Daniell, K.A., Coombes, J. \& White, I. (2014). Politics of Innovation in Multi-level Water Governance Systems. Journal of Hydrology, 519(Part C): 2415-35. doi.org/10.1016/j.jhydrol.2014.08.058

Daniell, K.A., Máńez Costa, M.A., Ferrand, N., Kingsborough, A.B., Coad, P. \& Ribarova, I.S. (2010a). Aiding Multi-level DecisionMaking Processes for Climate Change Mitigation and Adaptation. Regional Environmental Change 11(2): 243-258.

Daniell, K.A., Mazri, C. \& Tsoukiàs, A. (2010b). Real World DecisionAiding: a case of participatory water management. In: Rios Insua, D. \& French, S. (eds) e-Democracy: A Group Decision and Negotiation Perspective. Advances in Group Decision and Negotiation Series, Vol. 5, Part 2. Springer, pp. 125-50. doi.org/10.1007/978-90-4819045-4_8 
Dare, M. \& Daniell, K.A. (2017). Australian water governance in the global context: Understanding the benefits of localism. Policy Studies, 38(5): 462-481. dx.doi.org/10.1080/01442872.2016.1188908

Dovers, S. (2013). The Australian Environmental Policy Agenda. Australian Journal of Public Administration, 72(2): 114-128. doi.org/ 10.1111/1467-8500.12013

Drought Policy Review Expert Social Panel (2008). It's About People: Changing Perspective. A Report to Government by an Expert Social Panel on Dryness. Report to the Minister for Agriculture, Fisheries and Forestry, Canberra, September, www.agriculture.gov.au/SiteCollection Documents/ag-food/drought/publications/dryness_report.pdf [Accessed: 18/07/2017].

Evans, M., Marsh, D. \& Stoker, G. (2013). Understanding Localism. Policy Studies, 34(4): 401-07. doi.org/10.1080/01442872.2013.822 699

Fischer, F. (2000). Citizens, Experts, and the Environment. Duke University Press, Durham. doi.org/10.1215/9780822380283

Garnaut, J., Connell, P., Lindsay, R., \& Rodriguez, V. (2001). Country Australia: Influences on Employment and Population Growth. ABARE Research Report 2001:1. Canberra.

Gross, C. \& Dumaresq, D. (2014). Taking the Longer View: Timescales, Fairness and a Forgotten Story of Irrigation in Australia. Journal of Hydrology, 519(Part C): 2483-92. doi.org/10.1016/j. jhydrol.2014.08.056

Hogan, A. (2010). Beyond Merciless Critique - Reflections on the Contribution of Sociology in the Policy Space. Working Notes, Issue 1, 29 June, sociologyatwork.org/beyond-merciless-critique/ [Accessed: $13 / 12 / 14]$.

Hogan, A., Berry, H., Ng, S.P. \& Bode, A. (2010). Decisions Made by Farmers that Relate to Climate Change. Rural Industries Research and Development Corporation, Canberra. 
Hogan, A., Carson, D., Cleary, J., Donnelly, D., Houghton, K., Phillips, R. $\&$ Tanton, R. (eds) (2014). Community Adaptability Tool: Securing the Wealth and Wellbeing of Rural Communities. RIRDC Publication No. 14/041, Canberra, rirdc.infoservices.com.au/items/14-041 [Accessed: 12/12/14].

Hogan, A., Cleary, J., Lockie, S., Young, M. \& Daniell, K.A. (2015). Localism and the Policy Goal of Securing the Socio-Economic Viability of Rural and Regional Australia. In: Hogan, A. \& Young, M. (eds) Rural and Regional Futures. Routledge, London, pp. 260-81.

Hogan, A. \& Young, M. (2013). Visioning a Future for Rural and Regional Australia. Cambridge Journal of Regions, Economy and Society, 6: 319-30. doi.org/10.1093/cjres/rst005

Hogan, A. \& Young, M. (eds) (2015). Rural and Regional Futures. Routledge, London.

Hugo, G. (2001). What is Really Happening in Rural and Regional Populations? In: Rogers, M.F. \& Collins, Y.M.J. (eds) The Future of Australia's Country Towns. Centre for Regional Communities, La Trobe University, Bendigo.

Jessop, B. (2004). Multi-level Governance and Multi-level Metagovernance. In: Bache, I. \& Flinders, M. (eds) Multi-level Governance. Oxford University Press, pp. 49-74. doi.org/10.1093/ 0199259259.003 .0004

Kelly, M. (2010). Peregian Springs Urban Recycled Water Project. Statement by The Honourable Dr Mike Kelly AM MP, Tuesday 9 March 2010.

Knowles, C. (2011). Opening Address. Sustaining Rural Communities Conference, www.mdba.gov.au/media/mr/mdba-chair-mr-craigknowles-speech-sustaining-rural-communities-conference-narrabri [Accessed: 18/07/2017].

Lloyd, R., Harding, A. \& Hellwig, O. (2001). Regional Divide? A Study of Income Inequality in Australia. Sustaining Regions, 1(1): 17-30. 
Marks, G. (1993). Structural Policy and Multilevel Governance in the EC. In: Cafruny, A.W. \& Rosenthal, G.G. (eds) The State of the European Community, Vol 2: The Maastricht Debates and Beyond. Harlow Longman, Boulder, CO, pp. 391-410.

Marshall, G.R. (2008). Nesting, Subsidiarity, and Community-Based Environmental Governance beyond the Local Level. International Journal of the Commons, 2(1): 75-97. doi.org/10.18352/ijc.50

Maude, A. (2004). Regional Development Processes and Policies in Australia: a review of research 1990-2002. European Planning Studies, 12(1): 3-26. doi.org/10.1080/09654310310001635670

MDBA (2010). Guide to the proposed Basin Plan. Murray-Darling Basin Authority, Australian Government, Canberra.

Oliver, M. (1990). The Politics of Disablement. Macmillan, London. doi. org/10.1007/978-1-349-20895-1

—_. (1996). Understanding Disability - From Theory to Practice. Macmillan, London. doi.org/10.1007/978-1-349-24269-6

Ostrom, E. (1999). Coping with Tragedies of the Commons. Annual Review of Political Science, 2: 493-535. doi.org/10.1146/annurev. polisci.2.1.493

Pahl-Wostl, C. (2008). Climate Change - A Global Challenge for Water Governance. ExpoZaragoza 2008, www.zaragoza.es/contenidos/ medioambiente/cajaAzul/18S6-P3-Pahl\%20WostlACC.pdf

Pearson, L. \& Dare, M. (2014). Alternate Futures for Murray-Darling Basin Communities. MDBFutures Workshop presentation, 20 May 2014, Collaborative Research Network, University of Canberra.

Price, R. (2015). Rural Research and Regional Innovation - Are Past and Present Research Funding Policies Building Future Resilience in the Bush? In: Hogan, A. \& Young, M. (eds) Rural and Regional Futures. Routledge, London, pp. 226-46.

Productivity Commission (2005). Trends in Australian Agriculture. Canberra.

RDA (2017). RDA Reform. Regional Development Australia, rda.gov. au/review/ 
Rhodes, R.A.W. (1998). Beyond Westminster and Whitehall. UrwinHyman, London.

Rosenhead, J. \& Mingers, J. (eds) (2001). Rational Analysis for a Problematic World Revisited. John Wiley and Sons, Chichester.

Sabatier, A. (1988). An Advocacy Coalition Framework of Policy Change and the Role of Policy-Oriented Learning Therein. Policy Sciences, 21: 129-68. doi.org/10.1007/BF00136406

Slocum, N. (2003). Participatory Methods Toolkit: A Practitioner's Manual. King Baudouin Foundation and the Flemish Institute for Science and Technology Assessment (viWTA) in collaboration with the United Nations University - Comparative Regional Integration Studies (UNU/CRIS), unu.edu/hq/library/Collection/PDF_files/CRIS/PMT. pdf [Accessed: 10/12/10].

Smith, E. \& Pritchard, B. (2015). Australian Agricultural and Rural Policy Since World War II: the pursuit of agricultural efficiency. In: Hogan, A. \& Young, M. (eds) Rural and Regional Futures. Routledge, London, pp. 58-70.

Tennent, R. \& Lockie, S. (2015). Natural Resource Management in Australia: a historical summary. In: Hogan, A. \& Young, M. (eds) Rural and Regional Futures. Routledge, London, pp. 71-83.

Truss, W. (2014). Keynote Address. SEGRA 2014 Connecting Matters Conference, 8 October 2014, Alice Springs, minister.infrastructure. gov.au/wt/speeches/2014/wts024_2014.aspx [Accessed: 26/07/17].

UNESCAP (2010). What is Good Governance? United Nations Economic and Social Commissions for Asia and the Pacific, www.unescap.org/ sites/default/files/good-governance.pdf [Accessed: 26/07/2017].

Wentworth Group (2006). Australia's Climate is Changing Australia: The State of Australias Water. Wentworth Group of Concerned Scientists, www.myoung.net.au/water/publications/Australias_Climate_ is_Changing_Australia.pdf [Accessed: 18/07/17]. 
This text is taken from Multi-level Governance: Conceptual challenges and case studies from Australia, edited by Katherine A. Daniell and Adrian Kay, published 2017 by ANU Press, The Australian National University, Canberra, Australia.

dx.doi.org/10.22459/MG.11.2017.17 